that a specific group of cells in the anterior horn of the sacral spinal cord, known as Onuf's nucleus, may also be affected in the disease. ${ }^{3}$

Progressive autonomic failure with multiple system atrophy has an insidious onset. The first urinary symptoms are usually frequency and urgency, soon progressing to urge incontinence; men also complain of erectile impotence and failure of ejaculation. Eventually orthostatic hypotension supervenes and this, together with urinary incontinence, constitutes the most disabling feature of the syndrome.

On examination the bladder is usually impalpable, but the tone of the anal sphincter is reduced. The most important general physical sign of autonomic failure is a pronounced fall in blood pressure on standing. An intravenous urogram will generally show normal upper tracts, but the bladder is trabeculated and invariably there is incompetence of the proximal urethra - a feature which may be seen more easily on a cystogram with the patient erect. A cystometrogram will show involuntary detrusor contractions during filling of the bladder; but the magnitude of these is reduced in more advanced cases. The ability to produce a voluntary bladder contraction appears to be lost early in the disease. The explanation for these findings probably lies in the degenerative changes that affect the basal ganglia and midbrain; both the corpus striatum and the pontine nuclei have been shown to influence bladder activity in studies on animals. ${ }^{4}$ These more central effects are undoubtedly compounded by progressive loss of cells from the preganglionic autonomic neurones of the thoracolumbar and sacral spinal segments, which will eventually result in a decentralised bladder akin to that seen after injury to the pelvic nerves.

Patients who suffer from progressive autonomic failure with multiple system atrophy show a characteristic inability to contract the distal urethral sphincter to prevent urinary leakage. Electromyography of the urethral sphincter has confirmed that the innervation of the striated muscle of the urethra is severely affected in this disease. ${ }^{5}$ This seems to be the result of neuronal degeneration of Onuf's nucleus, which has been shown in experimental animals to be responsible for the innervation of the striated muscle of both anal and urethral sphincters. ${ }^{6}$ Why the motor neurones of Onuf's nucleus should be selectively affected in this condition while other anterior horn cells are largely spared is a matter for speculation. The converse seems to apply in motor neurone disease: amid severe generalised loss of anterior horn cells Onuf's nucleus remains intact. Clearly these cells differ in some fundamental way from other motor neurones.

The striated muscle of the urethral sphincter differs from other skeletal muscles in showing tonic electromyographic activity which persists even during sleep and light general anaesthesia. The only structure that bears close comparison is the cricoarytenoid muscle of the larynx, which is constantly active in order to maintain abducture tone-and this muscle, too, suffers denervation in patients who have progressive autonomic failure with multiple system atrophy. ${ }^{7}$ Conceivably, then, it is the property of tonic firing of these neurones-located in Onuf's nucleus in the case of the urethral sphincter, and in the nucleus ambiguus in the case of the larynx-that distinguishes them from the neurones of other skeletal muscles.

Since the degenerative neuronal loss that occurs in progressive autonomic failure and multiple system atrophy cannot be arrested, treatment of the bladder disturbances is at best supportive. Most important is the recognition of the diagnosis and avoidance of transurethral surgery, which inevitably exacerbates patients' symptoms. Unfortunately cholinergic agents do not seem to improve voluntary bladder contractions, and, though sympathomimetic drugs may

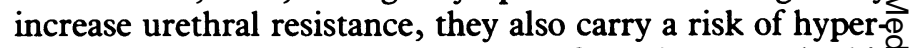
tension owing to the supersensitivity of agonist agents in thise disorder. Eventually urinary incontinence may need to bẹ treated by external urinary appliances in men and indwelling urethral catherterisation in women. The poor prognosis of patients suffering this condition generally rules out treat-s ment by implantation of artificial urinary sphincter devices.

Senior Urological Registrar,

Middlesex Hospital,

London WIN 8AA

Consultant Neurologist,

National Hospital for Nervous Diseases,

London WCIN 3BG

1 Bradbury A, Eggleston C. Postural hypotension: a report of three cases. Am Heart $\mathcal{f}$ 1925;1:73-86. 2 Shy GM, Drager GA. A neurological syndrome associated with orthostatic hypotension. ArchO Neurol 1960;2:511-27.

3 Sung JH, Mastri AR, Segal E. Pathology of the Shy-Drager syndrome. I Neuropathol Exp Neuro 1978;38:253-68.

4 Kuru M. Nervous control of micturition. Physiol Rev 1965;45:425-94.

5 Kirby RS, Fowler CJ, Gosling JA, Bannister R. Vesico-urethral dysfunction in progressiven autonomic failure with multiple system atrophy. F Neurol Neurosurg Psychiatry 1986;49:554-62.

6 Kuzuhara S, Kanazawa I, Nakanishi T. Topographical localization of Onuf's nuclear neurones innervating the rectal and vesical striated sphincter muscles: a retrograde fluorescent doublo labelling in cat and dog. Neurosci Lett 1980;16:125-30.

system atrophy with autonomic failure. $\mathcal{F}$ Neurol Neurosurg Psychiatry 1981;44:49-53.

\section{Graduated elastic stockings}

Elastic support stockings are of proved value in overcoming the effects of prolonged venous hypertension. ${ }^{12}$ If the valves of the deep veins or calf perforating veins have becom\& incompetent or if segments of the deep veins are occlude $\vec{F}$ after a thrombosis the high venous pressure developed by the calf muscle pump during standing or walking cannot be lowered effectively. ${ }^{3}$ The persistently raised venous pressure distends the dermal capillary bed ${ }^{4}$ and encourages large macromolecules (including fibrinogen), which are normally held within the vascular compartment, to escape into the tissues. $^{5}$ This is seen clinically as the development of lipodermatosclerosis, which precedes the development of venous ulceration. ${ }^{6}$

Elastic compression applied to the calf raises the loca interstitial pressure and decreases the superficial venous pressure, thereby reducing the leak of solutes and fluid into the interstitial space. The stockings also improve the venous return, seen as an increase in flow velocity through unocclu슈 ded deep and superficial veins. ${ }^{78}$ Compression enhances theु local release of plasminogen activator, ${ }^{9}$ which initiates extras vascular dissolution of fibrin and is therefore of potentiaf benefit in restoring defective fibrinolysis and stimulating thẹ? breakdown of pericapillary fibrin deposits responsible for the lipodermatosclerosis. ${ }^{10}$ All forms of compression squash the superficial venous channels and so relieve discomfort by preventing the excessive venous distension found in patients with varicose veins.

The first efforts to provide extrinsic calf compression wer\& made in the seventeenth century with rigid lace up stocking? applied over the lower calf in an attempt to heal ulceration. Elastic stockings in some form are thought to have been usect for over 150 years, but Sigg credits Van der Molen with the 
idea of graduating the level of elastic compression..$^{12}$ Sigg, in association with Ganzoni, developed "off the peg" graduated compression stockings based on the simple rationale that maximal compression should be exerted over the gaiter area, where lipodermatosclerosis and ulcers most commonly occur. He also developed the first crude "stocking tester," which measured the pressure developed beneath the stocking. Six years later Stemmer, using a combination of Starling's equation and the known range of venous pressures measured at the ankle in normal, varicose, and post-thrombotic legs, calculated that an external pressure of 35 to $40 \mathrm{~mm} \mathrm{Hg}$ at the ankle was required to prevent capillary transudation in legs with severe venous disease. ${ }^{13}$

Sigel and his colleagues showed that compression increased the velocity of blood flow in the deep veins of healthy people ${ }^{7}$ and found that optimal flows could be achieved by graduating the compression between $18 \mathrm{~mm} \mathrm{Hg}$ at the ankle and $8 \mathrm{~mm} \mathrm{Hg}$ in the mid-thigh. ${ }^{14}$ Using stockings developed to exert these "optimal" pressures, others were able to show a reduction in the incidence of postoperative deep vein thrombosis. ${ }^{15} 16$

Studies of the effects of graduated compression stockings on physiological tests of venous function in legs with chronic venous disease have shown a fall in the ambulatory venous pressure, ${ }^{17}$ an increase in the expelled calf volume on exercise, ${ }^{18}$ and an increase in the half return time in foot volumetric studies. ${ }^{19}$ Graduated stockings also increase the local capillary clearance ${ }^{19}$ and improve the capillary refilling time (J V Cornwall et al, paper presented to meeting of the Vascular Surgical Society of Great Britain and Ireland, 1985). All these benefits were minor or absent in the poorly compressive non-graduated garments used as controls in these studies.

The ideal of individual compression testing of all stockings is unlikely to be obtained on grounds of time and cost, but careful prescribing of stockings by experienced fitters is the least that our patients should be offered. Sadly, many hospitals seem unable to afford this service; but the provision of ill fitting stockings by inexperienced staff may be of little benefit. About $£ 5$ is added to the cost of each pair of below knee stockings if they are fitted by a contracted professional firm.

General practitioners cannot prescribe graduated compression stockings on an FP10. These must either be prescribed privately or be obtained through a hospital outpatient or surgical appliance department. This unsatisfactory arrangement should soon be over, however, since at last we have an agreed British Standards specification for graduated compression hosiery..$^{20}$ It has taken time to develop because of difficulties in deciding which test system to adopt. In the end the committee chose the Hosiery Trades Research Association (HATRA) test method, in which the tension developed by the fabric is measured after the garment is stretched over two flat bars arranged to give a simplified leg form. The tension that develops in the extended garment can then be measured at any point along its length and the reading converted to pressure. Recommendations are given for garments with pressure profiles from 6 to $10 \mathrm{~mm} \mathrm{Hg}, 11$ to $18 \mathrm{~mm} \mathrm{Hg}$, and $19 \mathrm{~mm} \mathrm{Hg}$ and above with desirable levels of graduation. Regrettably, the higher compression levels recommended by the Swiss and Germans have not been taken up by the British Standards committee, since this is the range that appears to be of most value. ${ }^{21} 22$
At present the drug tariff in Britain for elastic hosiery clearly states the methods and yarn to be used in the manufacture of stockings but does not regulate the performance of the finished garment. The British Standards specification should overcome this and allow the prescription of suitable compression hosiery.

A few prospective clinical trials have shown that graduated stockings are effective in healing lipodermatosclerosis ${ }^{10}$ or preventing venous ulceration, ${ }^{23}$ but these have suffered from being combined with fibrinolytic enhancement treatment and from lack of control patients fitted with standard elastic hosiery. More clinical studies should now be undertaken on the value of graduated compression stockings in venous ulcer prophylaxis. We ought to know if it is ever necessary to prescribe full length stockings. What are the optimum compression ratios? How long can stockings provide adequate compression? How are they best prescribed? Should all patients after a deep vein thrombosis wear graduated elastic stockings for the rest of their lives to prevent the subsequent development of lipodermatosclerosis and ulceration?

All these questions remain unanswered, but the case for graduated compression seems clear, and we hope the government will soon allow their prescription on the standard drug tariff.

K G BURNAND Assistant director, surgical unit

G T LAYER

Department of Surgery,

St Thomas's Hospital

London SE1 7EH

Research fellow

1 Dodd H, Cockett FBC. The pathology and surgery of the veins of the lower limb. Edinburgh: Livingstone, 1956.

2 Stemmer R, Marescaux J, Furderer C. Compression treatment of the lower extremities particularly with compression stockings. The Dermatologist 1980;31:355-65.

3 Burnand KG, O'Donnell TF, Lea Thomas $M$. The relative importance of incompetent communicating veins in the production of varicose veins and venous ulcers. Surgery 1979;82: 9-14.

4 Burnand KG, Whimster I, Clemenson G, Thomas ML, Browse NL. The relationship between the number of capillaries in the skin of the venous ulcer-bearing area of the lower leg and the fall in foot vein pressure during exercise. Br $\mathcal{F}$ Surg 1981;68:297-300.

5 Burnand KG, Whimster I, Naidoo A, Browse NL. Pericapillary fibrin in the ulcer-bearing skin of the leg: the cause of lipodermatosclerosis and venous ulceration. Br Med $f$ 1982;285:1071-2. the leg: the cause of lipodermatosclerosis and venous ulceration. Br Med f 1982;
Browse NL, Burnand KG. The cause of venous ulceration. Lancet 1982;ii:243-5.

6 Browse NL, Burnand KG. The cause of venous ulceration. Lancet 1982;ii:243-5. lower leg during inactive recumbency. Arch Surg 1973;106:38-43.
low

8 Meyerovitz BR, Nelson R. Measurements of the velocity of blood in lower limb veins with and without compression. Surgery 1965;56:481-6.

9 Clarke RL, Orandi A, Cliffton EE. Tourniquet induction of fibrinolysis. Angiology 1960;11: 367- 70.

10 Burnand KG, Clemenson G, Morland M, Jarrett PGM, Browse NL. Venous lipodermatosclerosis: treatment by fibrinolytic enhancement and elastic compression. Br Med $\mathcal{f}$ 1980;280 7-11.

11 Wiseman R. Severall chirurgicall treatises. London: Royston and Tooke, 1676.

12 Sigg K. Compression with pressure bandages and elastic stockings for prophylaxis and therapy of venous disorders of the leg. Fortschr Med 1963;15:601-6.

13 Stemmer R. Ambulatory elasto-compressive treatment of the lower extremities particularly with elastic stockings. Der Kassenarzt 1969;9:1-8.

14 Sigel B, Edelstein AL, Savitch L, Hasty JH, Felix WR. Types of compression for reducing venous stasis. Arch Surg 1975;110:171-5.

15 Holford CP. Graded compression for preventing deep vein thrombosis. Br Med 7 1976;ï:969-70.

16 Scurr JH, Ibrahim SZ, Faber RG, LeQuesne LP. The efficacy of graduated compression stockings in the prevention of deep vein thrombosis. Br $\mathcal{F}$ Surg 1977;64:371-3.

17 Horner J, Fernandes E, Fernandes J, Nicolaides AN. Value of graduated compression stockings in deep venous insufficiency. $\operatorname{Br} M e d \mathcal{F} 1980 ; 280: 820-1$.

18 Partsch H. Do we need firm compression stockings exerting high pressure? Vasa 1984;13:52-7.

19 Jones NAG, Webb PJ, Rees RI, Kakkar VV. A physiological study of elastic compression stockings in venous disorders of the leg. $B r \mathcal{F}$ Surg 1980;67:569-72.

20 British Standards Institution. British Standards specification for graduated compression hosiery. London: British Standards Institution, 1985. (BS 6612:1985.)

21 Interkantonale Kontrollstelle fur Heilmittel. Guidelines on the examination, evaluation and registration of medical stockings. Berne: Interkantonale Kontrollstelle fur Heilmittel, 1976.

22 Association of Physicians in the Federal German Health Service. Prescription on medical stockings. Kassenarztliche Bundesvereinigung. October 1974. (Memorandum No 5.)

23 Burnand KG, Pattison M, Browse NL. The results of a course of Stromba treatment on lipodermatosclerosis: a five year follow-up. In: Davidson JF, Bachmann $F$, Bouvier CA, Kruithof EKO, eds. Progress in fibrinolysis. Vol 6. Edinburgh: Churchill Livingovier CA, 526-8. 